\title{
Modeling groundwater probability index in Ponnaiyar River basin of South India using analytic hierarchy process
}

\author{
A. Jothibasu' ${ }^{1} \cdot$ S. Anbazhagan ${ }^{1}$
}

Received: 23 April 2016/ Accepted: 5 June 2016/Published online: 20 June 2016

(C) Springer International Publishing Switzerland 2016

\begin{abstract}
In the present study, an effort has been made to investigate the analytical hierarchy process has been applied to delineate groundwater potential based on integrated geographic information system (GIS) and remote sensing (RS) techniques in Ponnaiyar River basin, Tamil Nadu, India. At first, the climatic factor, topographic factors, water related factors, geological factors, hydrogeological factors and other ecological factors such as land use/land cover and soil depth were derived from the spatial geo-database. Secondly, the 74 groundwater data with high potential yield values of $\geq 40 \mathrm{~m}^{3} / \mathrm{h}$ were collected and mapped in GIS. Out these, 44 (60\%) cases were randomly selected for models training, and the remaining $31(40 \%)$ cases were used for the validation purposes. Then, the assigned weights of thematic layers based on expert knowledge were normalized by eigenvector technique of AHP. To prepare the groundwater potential index, the weighted linear combination (WLC) method was applied in GIS. Finally, the receiver operating characteristic (ROC) curve was drawn for groundwater potential map, and the area under curve (AUC) was computed. Results indicated that the rainfall and slope percent factors have taken the highest and lowest weights, respectively. Validation of results showed that the AHP method (AUC $=76.90 \%$ ) performed fairly good predication accuracy. Results of this study could be helpful for better management of
\end{abstract}

A. Jothibasu

ajbasu.a09@gmail.com

S. Anbazhagan

anbu02@gmail.com

1 Centre for Geoinformatics and Planetary Studies, Department of Geology, Periyar University, Salem 636 011, Tamil Nadu, India groundwater resources in the study area and give planners and decision makers an opportunity to prepare appropriate groundwater investment plans for sustainable environment.

Keywords Analytic hierarchy process - GIS . Groundwater probability index - Ponnaiyar river basin . India

\section{Introduction}

In recent decades it has become evident in many countries of the world that groundwater is one of the most important natural resources (Zektser and Everett 2004). The quality of groundwater over surface water is that it is less affected by catastrophic events, and it can be tapped when required, exploitation of groundwater as alternative to inadequacy of surface water is ever increasing (Manap et al. 2013). Hence, it is necessary to recognize the methods to approach towards groundwater management and to predict the groundwater potential at the national, regional, and local scales (Anbazhagan et al. 2000; Vaux 2011; Page et al. 2012). Therefore, groundwater potential mapping (GPM) is essential, and it can be one of the preliminary steps toward managing the groundwater resources. As a result, researchers have demonstrated that constructing a GPM constitutes an effective way to explore these invaluable natural resources (Anbazhagan et al. 2001; Madan et al. 2010; Oh et al. 2011; Adiat et al. 2012; Manap et al. 2013). There are several methods for assessing the groundwater status (Anbazhagan 2004; Pradhan 2009; Nampak et al. 2014). Recently, GIS has also provided another cost and time effective approaches of spatial prediction of groundwater productivity (Jha Arkoprovo et al. 2012; Manap et al. 2014; Anbazhagan and Jothibasu 2016a, b). GIS technique is a popular tool to handle huge amount of spatial data 
and can be utilized in several fields in environmental and water resources management (Anbazhagan and Ramasamy 1997; Chowdhury et al. 2009; Dar et al. 2010; Gaur et al. 2011; Magesh et al. 2012; Rahmati et al. 2014b). Several studies have been applied using index based models for producing the GPM (Solomon and Quiel 2006; Prasad et al. 2008; Elewa and Qaddah 2011; Manap et al. 2014). In some studies, analytical hierarchy process (AHP) (Jha et al. 2010; Machiwal et al. 2011; Adiat et al. 2012; Kaliraj et al. 2014; Rahmati et al. 2014a; Shekhar and Pandey 2014; Naghibi et al. 2014; Nazari et al. 2012; Neshat et al. 2013; Nosrati and Eeckhaut 2012; Ozdemir 2011a, b; Pourghasemi and Beheshtirad 2014; Pourghasemi et al. 2013a, b; Pradhan and Lee 2010; Shahid et al. 2002; Singh and Prakash 2003), have been used for groundwater potential mapping.

Adiat et al. (2012) used the analytic hierarchy process (AHP) for groundwater potentiality mapping in Kedah, Peninsula Malaysia. Machiwal et al. (2011) utilized the AHP method for spatial prediction of groundwater potentiality in Udaipur, India. Their results indicated that AHP requires questionnaires of comparison ratings to define the weights for the thematic layers in groundwater potentiality analysis. Remote sensing and geographic information system (GIS) technologies have great potential for use in groundwater hydrology. GIS is a powerful tool for handling spatial data and decision making in several areas, including geological and environmental fields (Stafford 1991; Goodchild 1993). Remote sensing is one of the main sources of information about surface features related to groundwater such as lineament, land use, and landforms. Such information can be easily input to a GIS environment for integration with other types of data, followed by analysis (Faust et al. 1991; Hinton 1996; Jha et al. 2007). The main objective of this study is to assess the competence of the AHP model for groundwater probability index at Ponnaiyar River basin, Tamil Nadu, India. The GPI will be helpful to the decision makers in groundwater resource management and identifying prone areas for future plans. Also, this research is essential for rapid identifying of groundwater resource potential in the study area. Population growth and inadequate public water supply have led to increased demand for groundwater in Tamil Nadu during the past decade. Meanwhile, these models are almost new in groundwater probability mapping, and the efficiency and capability of them can be examined. Therefore, to assess the groundwater probability, an effective and low expense approach is needed for preventing the undesirable effects of future plans.

\section{Study area}

Ponnaiyar River basin an interstate river is one of the largest rivers of the state of Tamil Nadu, often reverently called 'Little Ganga of the South'. The river has supported may a civilizations of peninsular India across the history and continues to play a vital role in supplying precious water for drinking, irrigation and industry to the people of the states of Karnataka, Tamil Nadu and Pondicherry. The study area extends over approximately of $11,595 \mathrm{sq} . \mathrm{km}$, and lies between $11^{\circ} 35^{\prime}$ and $12^{\circ} 35^{\prime} \mathrm{N}$ latitudes and $77^{\circ} 45^{\prime}$ and $79^{\circ} 55^{\prime} \mathrm{E}$ longitudes (Fig. 1). Ponnaiyar River originates on the south eastern slopes of Chennakesava Hills, northwest of Nandidurg of Kolar district in Karnataka State at an altitude of 1000 m above mean sea level (amsl). The total length of Ponnaiyar River is $432 \mathrm{~km}$ of which $85 \mathrm{~km}$ lies in Karnataka state, $187 \mathrm{~km}$ in Dharmapuri, Krishnagiri and Salem districts, $54 \mathrm{~km}$ in Thiruvannamalai and Vellore districts and $106 \mathrm{~km}$ in Cuddalore and Villupuram districts of Tamil Nadu. The Ponnaiyar basin is predominantly built up with granite and gneisses rocks of archean period. The granite is of very good quality and extensive outcrops and masses of it are commonly found. The chief components of rocks are hornblende and feldspar. Foliation is seldom seen. In the plains of reserve forest, quartz is found commonly. The diamond granite is also found in scattered pockets in the area of Chitteri hills in Dharmapuri and Krishnagiri sub-divisions. Charnockite rocks of archean period are also seen in some areas. Alluvium and sand-dunes of quaternary period are also seen at a few places. The 15 years (2000-2014) average annual rainfall in the basin is $969 \mathrm{~mm}$. The catchment falls under the tropical belt. The climate in general is hot; April and May being the hottest months of the year when the temperature rises to $34{ }^{\circ} \mathrm{C}$.

\section{Methodology}

The methodology can be attained from different groundwater conditioning factors. The climatic factor (rainfall), topographic factors (such as altitude, slope angle (degree), slope aspect, topographic curvature), water related factors (topographic wetness index, stream power index, distance to main river and drainage density), geological factors (lithology, fault density), hydrogeological factors (depth to water level) and other ecological factors such as land use/land cover and soil depth were prepared using remote sensing and GIS. The second step the well training and validation dataset have been prepared. Finally, using these factors, the groundwater probability index of AHP, map was generated with validation and interpretation of the results. The methodologies adopted in the present study are shown in Fig. 2.

\section{Climatic factors}

The main climatic factor of rainfall (Rf) is one of the most important hydrologic parameters and it was considered as a major source of recharge (Musa et al. 2000; Magesh et al. 


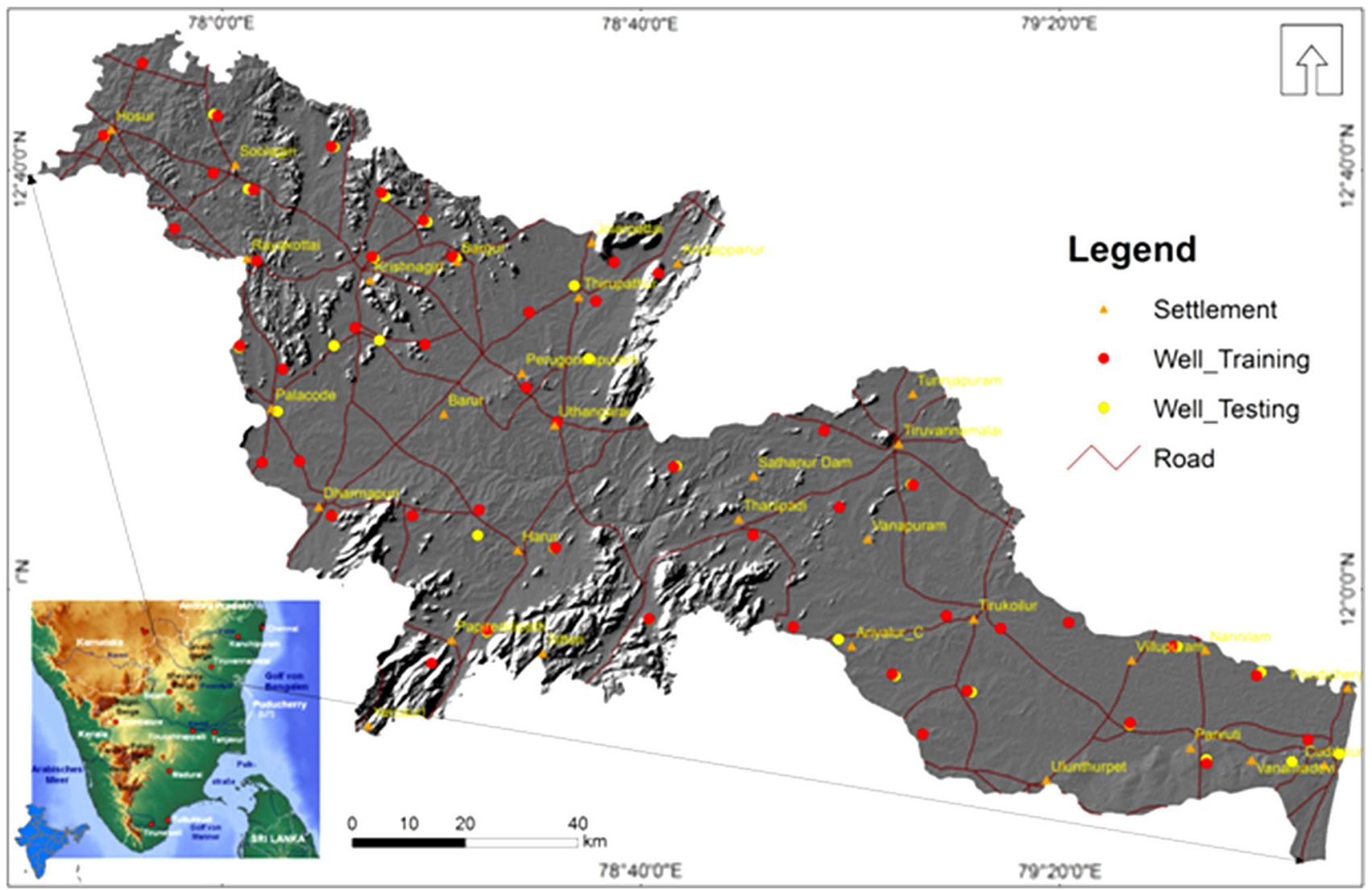

Fig. 1 Study area and groundwater well locations of Ponnaiyar river basin

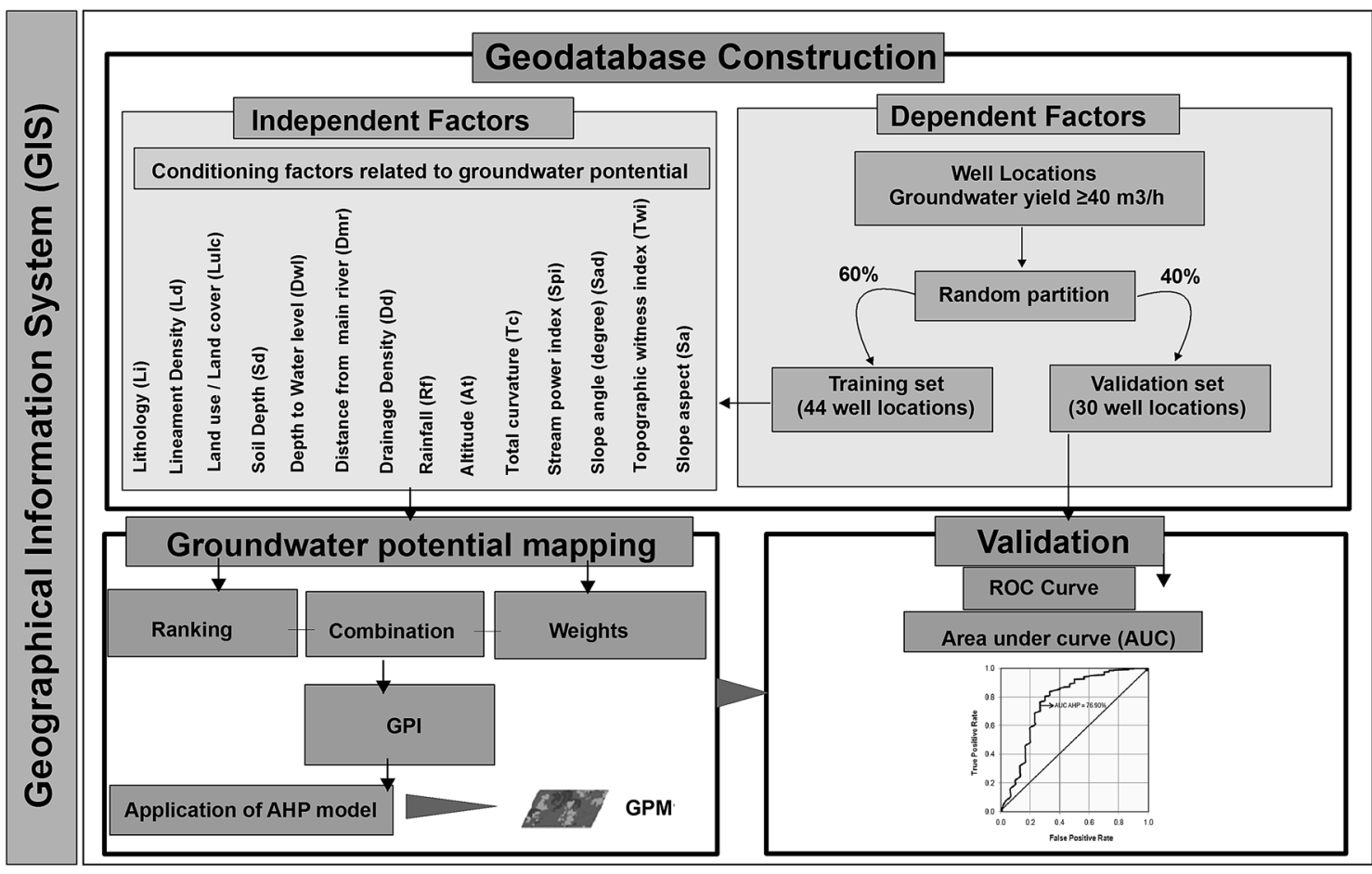

Fig. 2 Flowchart showing the methodology adopted in this study 
2012; Shekhar and Pandey 2014). It is an important element to assess the water input to the basin and to understand the flourish or deficit condition of water resource Anbazhagan and Jothibasu 2016a, b). Adiat et al. (2012) proved that the rainfall has a significant effect on percolation and groundwater potential mapping accuracy. The monthly records of rainfall amount for thirty rain-gauge stations within the study area for a period of 15 years (2000-2014) were obtained from the Tamil Nadu State Surface and Groundwater Division database. The resulting map was classified into five major classes: 688-850, 850-923, 923-987, 987-1046, and 1046-1195 mm/year (Fig. 3a). Average annual rainfall in the study area varies in the range of 688 to $1195 \mathrm{~mm}$. North eastern and south western part receive high rainfall $(>987 \mathrm{~mm})$ whereas southeastern and northwestern part receive low rainfall ( $<923 \mathrm{~mm}$ ). High rainfall reported during the period from 2005 to 2010 indicates that the ground water regime got highly recharge, whereas low rainfall reported during the year 2000 to 2004, contribute less to ground water aquifer and that period faced severe drought condition.

\section{Topographic factors}

The altitude (At), slope angle (degree) (Sad), and slope aspect $(\mathrm{Sa})$ topographic curvature $(\mathrm{Tc})$ can be considered as surface indicators for assessing the groundwater potential (Ettazarini 2007; Al Saud 2010). SRTM satellite data were applied to create a digital elevation model (DEM) of the study area with spatial resolution of $90 \mathrm{~m}$. Different altitudes have altered climate conditions, and this caused differences in soil condition and vegetation type (Aniya 1985). Altitude (At) map of the study area was created from the DEM. The altitude map was grouped into six classes: -4 to 205, 205-386, 386-556, 556-750, 750-1009, and 1009-1635 m based on the quantile classification method (Fig. 3b) (Tehrany et al. 2013). Slope angle (degree) (Sad) largely controls the groundwater recharge processes, infiltration and runoff (Sarkar et al. 2001; Ettazarizini and El Mahmouhi 2004; Prasad et al. 2008), therefore, it is an effective factor for the spatial prediction of groundwater potential. The slope map of the study area was generated based on DEM using the Spatial Analysis tools in ArcGIS 9.3. Based on the quantile classification scheme (Tehrany et al. 2014), the slope angle map was grouped into six classes such as $<7^{\circ}, 7^{\circ}-15^{\circ}, 15^{\circ}-$ $20^{\circ}, 20^{\circ}-25^{\circ}, 25^{\circ}-30^{\circ}$, and $>30^{\circ}$ (Fig. 3c). Slope aspect (Sa) aspect is related to the main precipitation direction and the physiographic trends (Ercanoglu and Gokceoglu 2002). Slope aspect layer was extracted from DEM and divided into nine classes including ten directions and flat based on normal or common standard classification (Fig. 3d).
Topographic curvature (Tc) was calculated from the DEM (Fig. 3e). The map comprises five classes ranging from very high class to very low class. Negative values for curvature $(<-2)$ correspond concave and accumulation zones, zero values for curvature represent the flat and transitional zones and the positive values for curvature represent the convex and dissipation zones (Florinsky 2000). The very high classes are reflecting high value (4.97) for the frequency ratio, suggesting high infiltration and for potential groundwater.

\section{Water related factors}

There is a vital role for topography in the spatial variation of hydrological conditions such as soil moisture and groundwater flow. Therefore, the secondary topographic indices have been used for describing spatial soil moisture patterns (Moore et al. 1991). Various factors such as topographic wetness index (TWI), stream power index (SPI), drainage density (Dd) and distance from main rivers (Dmr) play significant roles in hydro-geological systems. Topographic Witness Index (TWI) has been widely used to explain the impact of topography conditions on the location and size of saturated source zones of surface runoff generation. Recently, TWI has been used for groundwater potential mapping (Davoodi Moghaddam et al. 2013; Nampak et al. 2014) and describing spatial wetness patterns (Pourghasemi et al. 2012a; Pourtaghi and Pourghasemi 2014). It is defined as (Moore et al. 1991):

$T W I=\operatorname{In}\left(\frac{A_{s}}{\tan \beta}\right)$

where, $A_{S}$ is the cumulative upslope area draining through a point (per unit contour length) and

$\beta$ is the slope gradient (in degree).

In this study, TWI map is grouped into four classes using quantile classification scheme (Tehrany et al. 2014) (Fig. 3f). The tendency of water to accumulate at any point in the catchment (in terms of $\alpha$ ) and the tendency of gravitational forces to move that water down slope (indicated in terms of $\tan b$ as an approximate hydraulic gradient) are considered by the $\ln \beta \tan \alpha$ index. Primarily, the water infiltration depends upon material properties such as permeability and pours water pressure on the soil strength.

Stream Power Index (SPI) is a measure of the erosive power of water flow based on the assumption that discharge $(\mathrm{q})$ is proportional to specific catchment area (As) (Eq. 2) (Moore et al. 1991)

$\mathrm{SPI}=\mathrm{Bs} \mathrm{x}$ tana

where, Bs is the specific catchment area $\left(\mathrm{m}^{2}\right) \tan \alpha$ the local slope gradient measured in degrees 


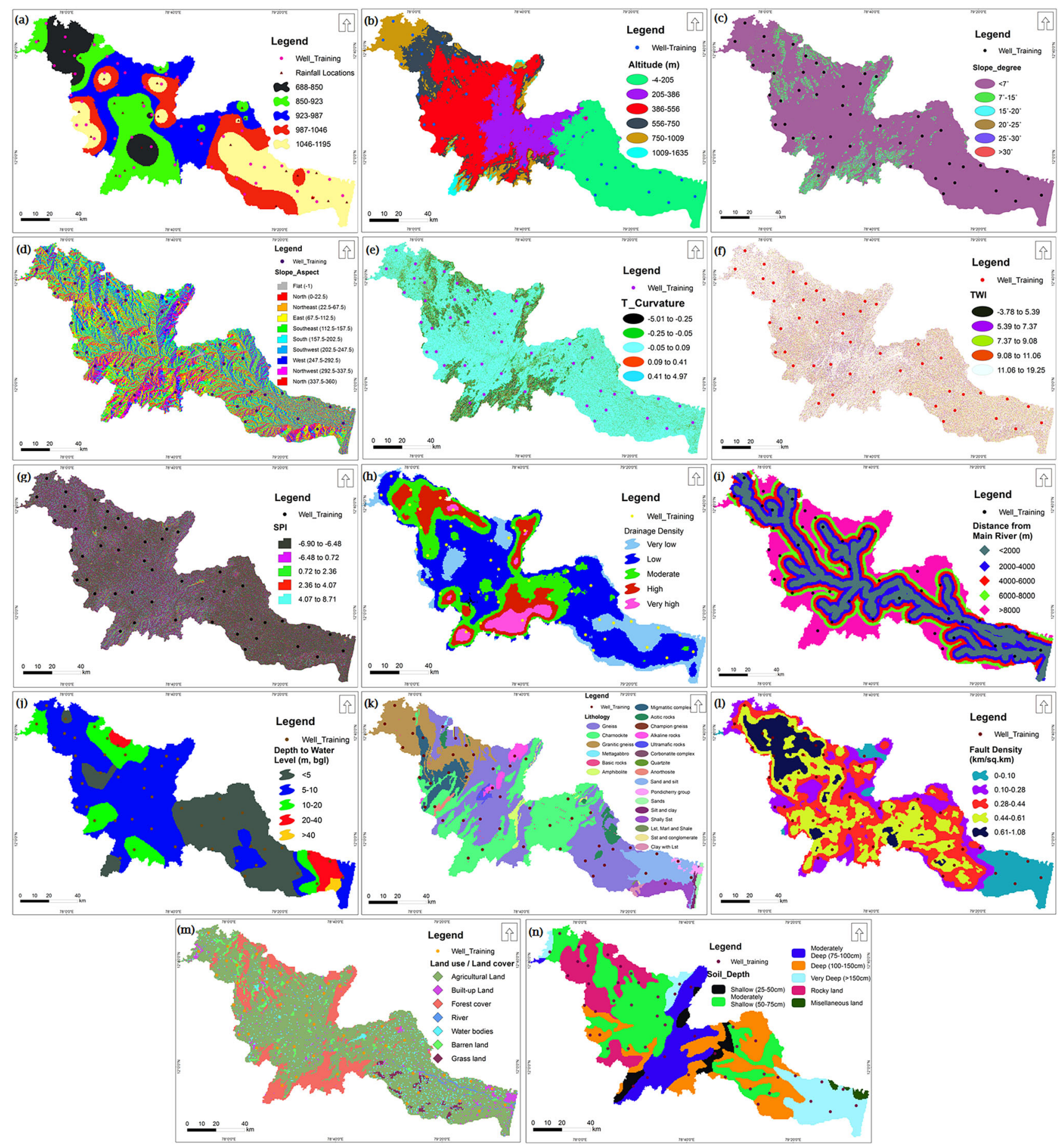

Fig. 3 Climatic and groundwater conditioning factors of Ponnaiyar river basin; a Rainfall, b altitude, c slope angle (degree), d slope aspect, e topographic curvature, f TWI, g SPI, h drainage density,

As the specific catchment's area and gradient increase, the amount of water contributed by upslope areas and the velocity of water flow increase; hence, the SPI and slopeerosion risk increase (Moore et al. 1991). Moore et al. (1993) stated that the SPI controls the potential erosive power of overland flow. Therefore, these processes can be $\mathbf{i}$ distance from main river, $\mathbf{j}$ depth to water level, $\mathbf{k}$ lithology, $\mathbf{I}$ fault density, $\mathbf{m}$ land use/land cover, and $\mathbf{n}$ Soil depth

considered as one of the components of groundwater potential occurrence (Nefeslioglu et al. 2008; Yilmaz 2009; Akgun and Turk 2010). The SPI demarcated into five classes based on Jenk natural break (Fig. 3g).

Drainage density $(\mathrm{Dd})$ : The drainage system of an area is determined by the nature and structure of the geological 
formation (bedrock), rainfall absorption capacity of soils, vegetation type, infiltration rate and slope angle (Manap et al. 2014). Drainage density is considered as the closeness of spacing of stream channels (Magesh et al. 2012) and a high drainage density causes lower infiltration and increased surface runoff. It means that drainage density is an inverse function of permeability hence; areas having high drainage density are not suitable for groundwater development (Dinesh Kumar et al. 2007). In order to determine drainage density of study area, Line Density tool in ArcGIS 9.3 was used. The drainage density quantity of study area was computed through sum of lengths of streams in the mesh $(\mathrm{km})$, and area of the grid $\left(\mathrm{km}^{2}\right)$. The drainage density map of the study area was divided to five classes such as very low $\left(<0.72 \mathrm{~km} / \mathrm{km}^{2}\right)$, low (0.72-1.45), moderate (1.45-2.17), high (2.17-2.90) and very high ( $>2.90)$ (Fig. 3h), and it reveals that high drainage density is observed in the center of the study area. Distance from main river (Dmr) is one of the main conditioning factors due to its significant impact on the groundwater potential spread and magnitude (Fernández and Lutz 2010; Glenn et al. 2012). It is an important parameter that controls the stability of a slope is the saturation degree of the material on the slope. The closeness of the slope to drainage structures is another important factor in terms of stability. Streams may adversely affect stability by eroding the slopes or by saturating the lower part of material until resulting in water level increases (Gokceoglu and Aksoy 1996). The distance from river map was produced using the buffer tool in ArcGIS 9.3 and was classified into five classes (Fig. 3i).

\section{Hydrogeological factors}

Rao and Briz-Kishore (1991) indicated that water level is one of the most important hydro-geological factors and can be applied to evaluate groundwater potential. The water table level (Wt) dataset of the study area was acquired from the State Surface and Groundwater Division. According to Bevan et al. (2005) water table level is defined as the surface at which pore pressure is equal to atmospheric pressure. Water table level indicates hydraulic gradients of any point, hence, it can be useful to identify the area with high groundwater potential (Madrucci et al. 2008). In the present study, the depth to dater level (Dwl) varies from $<5$ to $>40 \mathrm{~m}$ (Fig. 3j).

\section{Geological factors}

The lithology is considered as one of the most important indicators of hydro-geological features which play a fundamental role in both the porosity and permeability of aquifer materials (Ayazi et al. 2010; Charon 1974). The analog lithology map $(1: 100,000)$ was obtained from the Geological Survey of India (GSI 1997) and the digital lithology map was generated using ArcGIS 9.3 (Fig. 3k). According to Geological Survey of India the lithology of the study area is varied and covered by 22 rock types. Fault density (Fd) generally control relief, spatial distribution of drainage networks and groundwater accumulation under the influence of slope (Samy et al. 2011; Gerrard 1981). In an image, a fault is defined as a straight or slightly curved surface feature of natural origin, interpreted directly from the imagery (O'Leary et al. 1976; Koike et al. 1998). Fault and intersections of lineaments reflect rock structures through which water can percolate and travel up to several kilometers within (Kane et al. 1996). In this study, fault zones were detected through interpretation of IRS P6 LISS III imagery and hill-shade maps from a DEM and mapping methodology adopted as drainage density (Fig. 31).

\section{Ecological factors}

Land use and soil is important ecological factors for life. Land use types play a significant role, which directly or indirectly influence on some of hydrological processes components such as infiltration, evapotranspiration and run-off generation. Land use types within the study area are agriculture land, built-up land, forest cover, river, water body, barren land, and grass land (Fig. 3m). Built-up areas, which are mostly made by impervious surfaces, increase the storm run-off and inundation (Tehrany et al. 2013). On the other hand, agricultural areas are less prone to flooding due to the positive relationship between infiltration capability and vegetation density. The land use/land cover map was prepared from IRS P6 LISS III image through supervised classification using maximum likelihood algorithm, and false color composite (FCC) techniques in ENVI 4.3 software. Soil is defined in different ways for different processes. Generally, it is a complex biogeochemical material on which plants may grow. Information on the type of soil is often needed as a basic input in hydrologic evaluation. Mapping soil usually involves delineating soil types that have identifiable characteristics. The delineation is based on many factors garment to soil science such as geomorphologic origin and conditions under which the soil formed (Vieux 2004). Soil depth is one of the most important factors in the surface and subsurface runoff generation and infiltration process (Mogaji et al. 2014). The soil depth map was obtained from the Central Groundwater Board (CGWB, 2012). There are four classes of soil depth in the study area (Fig. 3n). 


\section{Well yield data set}

In order to prepare groundwater database, well yield data of study area were collected from the State Surface and Groundwater Division, and extensive field surveys. Due to limited availability of the groundwater data, indirect indicator of yield measurement was applied in these models instead of hydraulic constants of specific capacity as considered by $\mathrm{Oh}$ et al. (2011). Groundwater yield is determined based on actual pumping test analysis of groundwater well e.g., $\mathrm{m}^{3} / \mathrm{h}$. About 74 groundwater productivity data with high potential yield values of $\geq 40 \mathrm{~m}^{3} / \mathrm{h}$ were collected from well locations. Out these, 44 (60\%) groundwater data were randomly selected for training of the models and the remaining $30(40 \%)$ were used for the validation purposes. Figure 1 shows the groundwater well locations (training and validation data set) in the study area.

\section{Results and discussion}

\section{Analytical hierarchy process (AHP) model}

The analytical hierarchy process (AHP) is firstly introduced by Saaty (1980). This approach allows group decisionmaking, where planners can use their scientific experience and knowledge to break down a problem into a hierarchy structure and solve it by the AHP process. AHP also provides facilitates decomposition and pairwise comparison, reduces inconsistency, and calculates priority vectors. The AHP model generally involves six steps (Hosseinali and Alesheikh 2008): (1) define the unstructured problem and objectives; (2) determine the detailed criteria and alternatives; (3) apply pair-wise comparisons to prepare comparison matrices; (4) use the eigenvalue technique to determine the relative weights of the decision factors; (5) compute the consistency index of the matrices; and (6) obtain an overall rating for the alternatives (by aggregating the weighted decision factors). In order to determine the weight of each conditioning factor, questionnaires of comparisons ratings based on Saaty's 1-9 scale (Saaty 1980) were prepared and filled by several experts (hydrologist, hydrogeologists, etc.) within study area (Table 1). Consequently, all the groundwater conditioning factors are compared against each other in a pair wise comparison matrix. The Expert Choice software package (E.C. Inc. 1995) has been used to determine the normalized weights of conditioning factors (priorities of alternatives) and to test for consistency ratio (CR). The following equation is used to compute the CR:

$C R=\frac{C I}{R I}$

where, RI is the random index whose value depending on the order of the matrix; and $\mathrm{CI}$ is the consistency index which can be obtained as:

$C I=\frac{\lambda_{\max }-n}{n-1}$

When, $\lambda$ is the largest eigenvalue of the matrix and can be easily determined from the mentioned matrix, and $n$ is number of groundwater conditioning factors.

According to Saaty (1980) and Malczewski (1999), the consistency ratio (CR) must be determined less than 0.1 . Consequently, all the conditioning factors are compared against each other in a pairwise comparison matrix

Table 1 Scale of relative importance suggested by Saaty (1997)

\begin{tabular}{|c|c|c|}
\hline $\begin{array}{l}\text { Intensity of } \\
\text { importance }\end{array}$ & Definition & Explanation \\
\hline 1 & Equal importance & Two activities contribute equally to objective \\
\hline 3 & $\begin{array}{l}\text { Weak importance of one } \\
\text { over another }\end{array}$ & Experience and judgment slightly favor one activity over another \\
\hline 5 & $\begin{array}{l}\text { Essential or strong } \\
\text { importance }\end{array}$ & Experience and judgment strongly favor one activity over another \\
\hline 7 & Demonstrated importance & $\begin{array}{l}\text { An activity is strongly favored and its dominance demonstrated in } \\
\text { practice }\end{array}$ \\
\hline 9 & Absolute importance & $\begin{array}{l}\text { The evidence favoring one activity over another is the highest } \\
\text { possible order of affirmation }\end{array}$ \\
\hline $2,4,6,8$ & $\begin{array}{l}\text { Intermediate values between } \\
\text { the two adjacent judgments }\end{array}$ & When compromise is needed \\
\hline
\end{tabular}


Table 2 Pair-wise comparison matrix for the AHP process in Ponnaiyar river basin

\begin{tabular}{|c|c|c|c|c|c|c|c|c|c|c|c|c|c|c|}
\hline Factor & $\mathrm{Li}$ & Ld & LULC & $\mathrm{Sd}$ & Dwl & Dfr & Dd & $\mathrm{Rf}$ & Tc & SPI & Sad & TWI & $\mathrm{Sa}$ & $\begin{array}{l}\text { Normalized } \\
\text { weight }\end{array}$ \\
\hline Lithology (Li) & 1 & 1 & 2 & 3 & 4 & 5 & 6 & 6 & 7 & 7 & 8 & 8 & 9 & 0.178 \\
\hline Lineament density (Ld) & 1 & 1 & 2 & 3 & 4 & 5 & 6 & 6 & 7 & 7 & 8 & 8 & 9 & 0.178 \\
\hline Land use land cover (LULC) & 2 & 2 & 1 & 2 & 3 & 4 & 5 & 6 & 6 & 7 & 7 & 8 & 8 & 0.133 \\
\hline Soil depth (Sd) & 3 & 3 & 2 & 1 & 2 & 3 & 4 & 5 & 6 & 6 & 7 & 7 & 8 & 0.100 \\
\hline Depth to water level (Dwl) & 4 & 4 & 3 & 2 & 1 & 2 & 3 & 4 & 5 & 6 & 6 & 7 & 7 & 0.078 \\
\hline Distance from river (Dfr) & 5 & 5 & 4 & 3 & 2 & 1 & 2 & 3 & 4 & 5 & 6 & 6 & 7 & 0.061 \\
\hline Drainage density (Dd) & 6 & 6 & 5 & 4 & 3 & 2 & 1 & 2 & 3 & 4 & 5 & 6 & 6 & 0.049 \\
\hline Raifall (Rf) & 6 & 6 & 6 & 5 & 4 & 3 & 2 & 1 & 2 & 3 & 4 & 5 & 6 & 0.039 \\
\hline Altitude (At) & 7 & 7 & 6 & 6 & 5 & 4 & 3 & 2 & 1 & 2 & 3 & 4 & 5 & 0.032 \\
\hline Total curvature $(\mathrm{Tc})$ & 7 & 7 & 7 & 6 & 6 & 5 & 4 & 3 & 2 & 1 & 2 & 3 & 4 & 0.025 \\
\hline Stream power index (SPI) & 8 & 8 & 7 & 7 & 6 & 6 & 5 & 4 & 3 & 2 & 1 & 2 & 3 & 0.019 \\
\hline Slope angle (Degree) (Sad) & 8 & 8 & 8 & 7 & 7 & 6 & 6 & 5 & 4 & 3 & 2 & 1 & 2 & 0.015 \\
\hline Tophographic wetness index (TWI) & 9 & 9 & 8 & 8 & 7 & 7 & 6 & 6 & 5 & 4 & 3 & 2 & 1 & 0.011 \\
\hline Slope aspect $(\mathrm{Sa})$ & 9 & 9 & 9 & 8 & 8 & 7 & 7 & 6 & 6 & 5 & 4 & 3 & 2 & 0.010 \\
\hline
\end{tabular}

Consistency ratio $(\mathrm{CR}=0.03<0.1)$

(Table 2). Furthermore, Table 2 presented the final weightings of conditioning factors. Ten groundwater conditioning factors were classified based on expert knowledge and literature review. Then, the rank of each condition factor class was determined according to expert knowledge and, subsequently, feature normalized ranks were extracted. Ranks assigned to different features of the individual factors and their normalized weights were shown in Table 3 (Rahmati et al. 2014a). The groundwater probability index (GWPI) is a dimensionless quantity that applies to perform the groundwater probability mapping in an area. The weighted linear combination (WLC) technique was used to determine the groundwater potential index (GWPI) as follows (Adiat et al. 2012; Shekhar and Pandey 2014):

$$
\begin{aligned}
G W P I= & R f_{w t} R f_{N r}+A t_{W t} A t_{N r} S a d_{w t} S a d_{N r}+S a_{w t} S a_{N r} \\
& +T c_{w t} T c_{N r}+T W I_{w t} T W I_{N r} \\
& +S P I_{w t} S P I_{N r} D d_{w t} D d_{N r}+D m r_{w t} D m r_{N r} \\
& +D w l_{w t} D w l_{N r}+L i_{w t} L i_{N r}+F d_{w t} F d_{N r} \\
& +L U L C_{w t} L U L C_{N r}+S d_{w t} S d_{N r}
\end{aligned}
$$

The GWPI values were grouped into four classes of low, moderate, high, and very high using the ArcGIS quantile classification method. In this classification method, each class contains the same number of features. Also, quantile method was applied by several researchers due to its efficiency (Nampak et al. 2014; Tehrany et al. 2014).

\section{Validation of the groundwater probability index}

From scientific significance viewpoint, validation is considered to be the most important process of modeling
(Chung and Fabbri 2003; Therefore, it is very important to evaluate the resultant GPI. The receiver operatingcharacteristics (ROC) curve was applied to determine the accuracy of the GPI (Davoodi Moghaddam et al. 2013; Pradhan 2013; Pourtaghi and Pourghasemi 2014). The GPI delineated in the current study was verified using the groundwater well locations in the validation datasets. Based on the groundwater yield data (with high potential yield values of $\geq 30 \mathrm{~m}^{3} / \mathrm{h}$ ) acquired from the State Surface and Groundwater Division, the accuracy assessment of the GPMs was made. The ROC curves were then obtained by considering cumulative percentage of probability index maps (on the $\mathrm{x}$ axis) and the cumulative percentage of groundwater occurrence (on the y axis) (Negnevitsky 2002; Pourghasemi et al. 2012b, c, d). The area under the curve (AUC) was calculated based on ROC curve analysis and it demonstrates the accuracy of a prediction system by describing the system's ability to expect the correct occurrence or non-occurrence of pre-defined "events" (Bui et al. 2012; Jaafari et al. 2014). According to Yesilnacar (2005) the quantitative-qualitative relationship between the AUC value and prediction accuracy can be grouped as follows: poor (0.5-0.6); average (0.6-0.7); good (0.7-0.8); very good (0.8-0.9); and excellent (0.9-1). Finally, all three classified models are verified through frequency percentage.

AHP is a model that has been widely used by different researchers in the field of natural resources and environmental management. The final weight of each conditioning factor was shown in Table 3 . The result of pair-wise comparison indicated that the soil depth, lithology, depth to 
Table 3 Assigned and normalized ranks of different features often conditioning factor for groundwater potential mapping in Ponnaiyar river basin

\begin{tabular}{lll}
\hline Factor $\quad$ Class $\quad$ Assigned rank & $\begin{array}{l}\text { Feature normalized } \\
\text { ranks }(\mathrm{Nr})\end{array}$ \\
\hline
\end{tabular}

\section{Lithology}

Gneiss

Charnockite

Granitic gneiss

Mettagabbro

Basic rocks

Amphibolite/

Migmatitic complex

Granitic/acidic rocks

Champion gneiss

Alkaline rocks

Ultramafic

Ultrabasic syenite

Quartzite

Anorthosite

Sand and silt

Pondicherry

Sands (coastal/alluvial)/

Alter seq of sand

Shaly sand stone

Lime stone, marl

Conglomerate

Clay with limestone

Lineament density (Ld)

$0-0.10 \mathrm{~km} / \mathrm{km}^{2}$

$0.10-0.28 \mathrm{~km} / \mathrm{km}^{2}$

$0.28-0.44 \mathrm{~km} / \mathrm{km}^{2}$

$0.44-0.61 \mathrm{~km} / \mathrm{km}^{2}$

$0.61-1.08 \mathrm{~km} / \mathrm{km}^{2}$

Land use land cover (LULC)

Agricultural land

Built-up land

Forest cover

River

Water bodies

Barren land

Grass land

Soil depth (Sd)

Shallow $(25-50 \mathrm{~cm})$

Moderately shallow $(50-75 \mathrm{~cm})$

Moderately deep

(75-100 cm)

Deep (100-150 cm)

Very deep $(>150 \mathrm{~cm})$

Rocky land
0.045

0.027

0.054

0.045

0.054

0.063

0.071

0.036

0.027

0.071

0.071

0.054

0.089

0.054

0.045

0.063

0.071

0.018

0.009

0.009

0.018

0.009

0.333

0.267

0.200

0.133

0.067

0.107

0.250

0.179

0.071

0.036

0.143

0.214

0.036

0.071

0.107

0.143

0.179

0.214
Table 3 continued

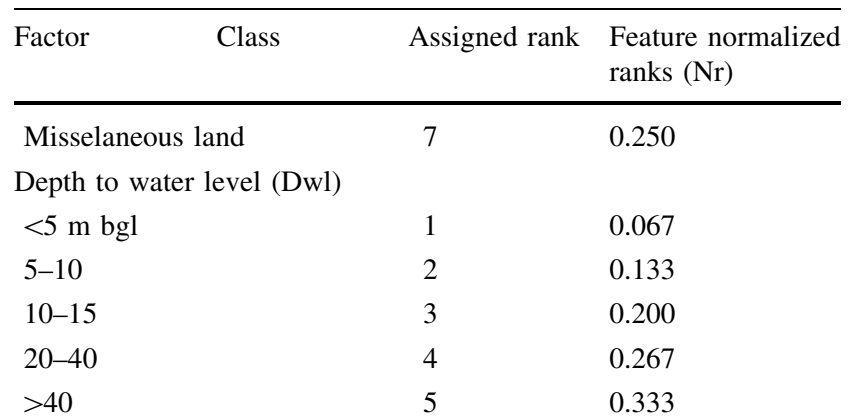

Distance from river (Dfr) $\mathrm{m}$

$<2000$

0.333

2000-4000

0.267

0.200

0.133

6000-8000

0.067

$>8000$

Drainage density (Dd)

Very low

0.067

Low

Moderate

High

Very high

0.133

0.200

0.267

0.333

Raifall (Rf)

688-850

0.067

850-923

923-987

0.133

987-1046

0.200

0.267

1046-115

0.333

Altitute (At)

-4-205

0.059

205-386

386-556

556-750

750-1009

1009-1635

0.118

0.176

0.176

0.235

0.235

Total curvature (Tc)

$-5.01-0.25$

$-0.25-0.05$

$-0.05-0.09$

0.09-0.41

0.41-4.97

0.333

0.267

0.200

0.133

Stream power index (SPI)

$-6.90-6.48$

0.313

$-6.48-0.72$

0.313

$0.72-2.36$

0.188

2.36-4.07

0.125

4.07-8.71

0.063

Slope angle (degree) (sad)

$<7^{\circ}$

0.286

$7^{\circ}-15^{\circ}$

0.238

$15^{\circ}-20^{\circ}$

0.190 
Table 3 continued

\begin{tabular}{lcl}
\hline Factor & Assigned rank & $\begin{array}{l}\text { Feature normalized } \\
\text { ranks (Nr) }\end{array}$ \\
\hline $20^{\circ}-25^{\circ}$ & 3 & 0.143 \\
$25^{\circ}-30^{\circ}$ & 2 & 0.095 \\
$>30^{\circ}$ & 1 & 0.048 \\
Tophographic wetness index (TWI) & \\
$-3.78-5.39$ & 5 & 0.313 \\
5.39-7.37 & 4 & 0.250 \\
$7.37-9.08$ & 4 & 0.250 \\
9.08-11.06 & 2 & 0.125 \\
11.06-19.25 & 1 & 0.063 \\
Slope aspect (Sa) & & \\
Flat (-1) & 4 & 0.125 \\
North (0-22.5) & 4 & 0.125 \\
Northeast (22.5-67.5) & 2 & 0.063 \\
East (67.5-112.5) & 3 & 0.094 \\
Southeast (112.5-157.5) & 3 & 0.094 \\
South (157.5-202.5) & 2 & 0.063 \\
Southwest (202.5-247.5) & 3 & 0.094 \\
West (247.5-292.5) & 3 & 0.094 \\
Northwest (292.5-337.5) & 4 & 0.125 \\
North (337.5-360) & 4 & 0.125 \\
\hline
\end{tabular}

water level and distance from river factors have taken the highest weights. In this study, the $\mathrm{CR}$ is 0.03 ; the ratio reflects a reasonable level of consistency in the pair-wise comparisons phase. Using the Eq. 5 the AHP model classified into four groups such as low, moderate, high very high probability. The final groundwater probability index map obtained by AHP model is shown in Fig. 4. Based on this map, high to very high groundwater probability zones are located at the eastern and northwestern region. Moreover, the middle parts of the study area because of low water level depth fall under very low groundwater probability. For quantitative validation, used of ROC curve analysis by comparing the existing groundwater well locations in the validation datasets with the groundwater probability map obtained by AHP model (Pradhan 2009, 2013; Mohammady et al. 2012; Davoodi Moghaddam et al. 2013; Regmi et al. 2013; Pourtaghi and Pourghasemi 2014). Figures 5 shows the ROC curve of the GPMs obtained using AHP model. Therefore, it can be seen that the AHP models applied in this study showed reasonably good accuracy in spatial predicting of groundwater probability. In AHP model frequency ration of well dataset indicates that the most of the wells fall under the moderate to low groundwater probability. It means that the well water level undergoes falling down in future. The effective watershed management will enhance the sustainable water environment which will be useful for the further planning and development of the area.

\section{Conclusion}

Groundwater probability analysis is one of the most popular areas of research, especially in arid and semi-arid regions. Various methods have been applied for regional groundwater potential assessment globally. Government and research institutions worldwide have tried for years to assess groundwater potential and predict its spatial distribution. In the present study, groundwater probability index maps have been prepared using AHP method with the
Fig. 4 Groundwater potential map of AHP

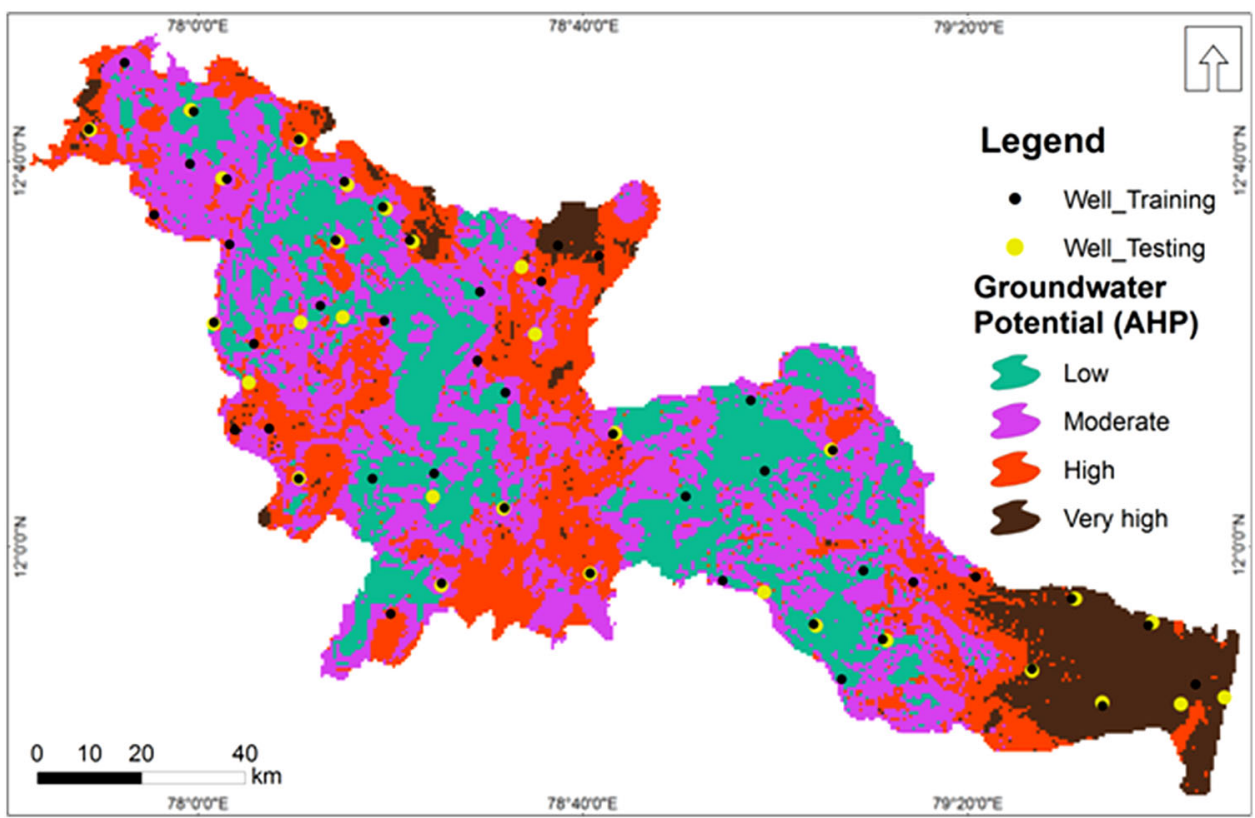




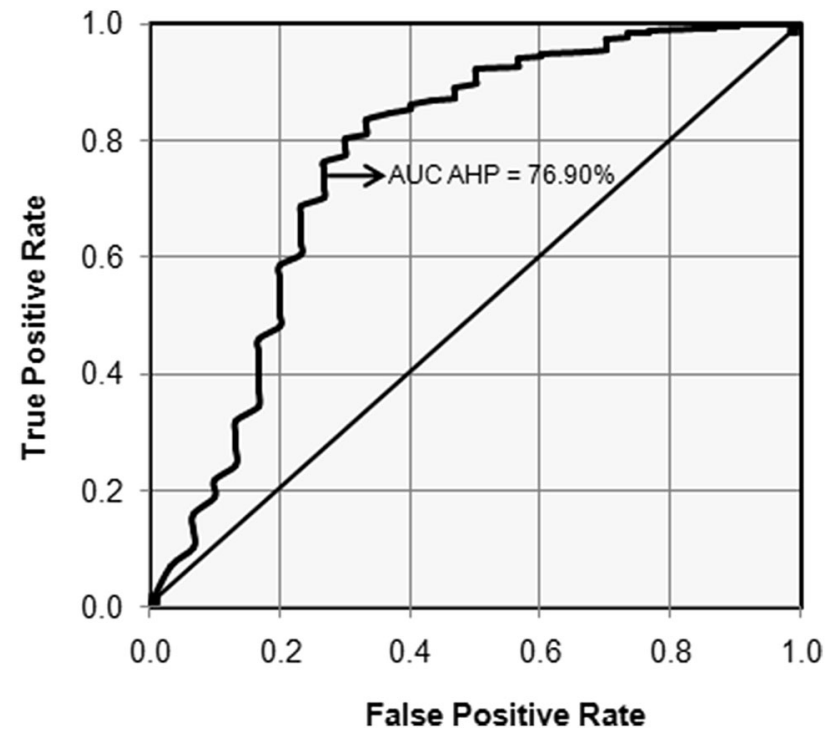

Fig. 5 ROC curve for the groundwater potential maps produced by AHP model of Ponnaiyar river basin

integration of remote sensing and GIS. The application of the AHP model is divided into three steps: the construction of database, the calculation of weights and the data integration and verification procedure, in which the obtained GPI was verified with ROC and groundwater well locations. In general, all used factors have relatively higher values of variation index implying the importance of all factors for accurate demarcation of groundwater probability. AHP approach is in agreement with the result obtained by other researchers used in groundwater probability assessment and various environmental studies. The validation of results demonstrated that the AHP has fairly good predication accuracy of $76.90 \%$. Hence, based on the results of this research and the accuracy of the derived groundwater potential prediction map, it can be concluded that the applied methodology, together with the used indices, is a useful framework for the rapid assessment of groundwater potential. The produced groundwater potential maps can assist planners and engineers in groundwater development plans and land use planning in the study area.

Acknowledgments The authors thank the State Surface and Groundwater Department for providing rainfall and water level data. The aquifer information published from the CGWB report was utilized. The first author acknowledges University Grants Commission (UGC), New Delhi, for granting a Post Doctoral Fellowship. The authors thank the anonymous reviewers for their valuable comments and suggestions to improve the content of the article.

\section{References}

Adiat K, Nawawi MNM, Abdullah K (2012) Assessing the accuracy of GIS-based elementary multi criteria decision analysis as a spatial prediction tool-a case of predicting potential zones of sustainable groundwater resources. J Hydrol 440:75-89

Akgun A, Turk N (2010) Landslide susceptibility mapping for Ayvalik (Western Turkey) and its vicinity by multi criteria decision analysis. Environ Earth Sci 61:595-611

Al Saud M (2010) Mapping potential areas for groundwater storage in wadi aurnah basin, western Arabian peninsula, using remote sensing and geographic information system techniques. Hydrogeol J 18:1481-1495

Anbazhagan S (2004) Geoinformatics for hydrological studies. In: Proceedings of regional colloquium an industry-academia meet on advanced materials, biosciences, and computers and information technology, Daman, pp 25-27

Anbazhagan S, Ramasamy SM (1997) Geophysical resistivity survey and potential site selection for artificial recharge, India. In: Marinos PG et al (ed) International symposium on engineering geology and environment. Athens, 2, pp 1169-1173

Anbazhagan S, Ramasamy SM, Moses Edwin J (2000) Remote sensing and geophysical resistivity survey for groundwater exploration-a comparative analysis. In: Conference on groundwater exploration techniques, Tiruchirappalli, pp 177-181

Anbazhagan S, Aschenbrenner F, Knoblich K (2001) Comparison of aquifer parameters with lineaments derived from remotely sensed data in kinzig basin. In: XXXI. IAH Congress: new approaches to characterizing groundwater flow. Germany, Munich, 2, pp 883-886

Anbazhagan S, Jothibasu A (2016a) Groundwater Sustainability Indicators in Parts of Tiruppur and Coimbatore Districts, Tamil Nadu. J Geol Soc India 87:161-168

Anbazhagan S, Jothibasu A (2016b) Geoinformatics in groundwater potential mapping and sustainable development: a case study from southern India. Hydrol Sci J 61(6):1109-1123

Aniya M (1985) Landslide-susceptibility mapping in the amahata river basin, Japan. Ann Assoc Am Geogr 75(1):102-114

Arkoprovo B, Adarsa J, Shashi Prakash S (2012) Delineation of groundwater potential zones using satellite remote sensing and geographic information techniques: a case study from Ganjam district, Orissa, India. Res J Recent Sci 9:59-66

Ayazi MH, Pirasteh S, Arvin AKP, Pradhan B, Nikouravan B, Mansor $S$ (2010) Disasters and risk reduction in groundwater: Zagros mountain southwest Iran using geo-informatics techniques. Dis Adv 3(1):51-57

Bevan MJ, Endres AL, Rudolph DL, Parkin G (2005) A field scale study of pumping-induced drainage and recovery in an unconfined aquifer. J Hydrol 315:52-70

Bui DT, Pradhan B, Lofman O, Revhaug I, Dick OB (2012) Landslide susceptibility mapping at Hoa binh province (Vietnam) using an adaptive neuro-fuzzy inference system and GIS. Comput Geosci 45:199-211

Charon JE (1974) Hydrogeological applications of ERTS satellite imagery. In: Proc UN/FAO regional seminar on remote sensing of earth resources and environment. Commonwealth Science Council, Cairo, pp 439-456

Chowdhury A, Jha MK, Chowdary VM, Mal BC (2009) Integrated remote sensing and GIS-based approach for assessing groundwater potential in west medinipur district, west Bengal. India. Int J Remote Sens 30(1):231-250

Chung JF, Fabbri AG (2003) Validation of spatial prediction models for landslide hazard mapping. Nat Hazards 30(3):451-472

Dar IA, Sankar K, Dar MA (2010) Remote sensing technology and geographic information system modeling: an integrated approach towards the mapping of groundwater potential zones in Hardrock terrain, Mamundiyar basin. J Hydrol 394:285-295

Davoodi Moghaddam D, Rezaei M, Pourghasemi HR, Pourtaghie ZS, Pradhan B (2013) Groundwater spring potential mapping using 
bivariate statistical model and GIS in the taleghan watershed Iran. Arab J Geosci. doi:10.1007/s12517-013-1161-5

Dinesh Kumar PK, Gopinath G, Seralathan P (2007) Application of remote sensing and GIS for the demarcation of groundwater potential zones of a river basin in Kerala, southwest cost of India. Int J Remote Sens 28(24):5583-5601

E.C. Inc. (Expert Choice Inc.) (1995) Decision support software: tutorial, expert choice, student version 9. Expert Choice Inc., Pittsburgh

Elewa HH, Qaddah AA (2011) Groundwater potentiality mapping in the Sinai peninsula, Egypt, using remote sensing and GISwatershedbased modeling. Hydrogeol J 19:613-628

Ercanoglu M, Gokceoglu C (2002) Assessment of landslide susceptibility for a landslide prone area (north of Yenice, NW Turkey) by fuzzy approach. Environ Geol 41:720-730

Ettazarini S (2007) Groundwater potential index: a strategically conceived tool for water research in fractured aquifers. Environ Geol 52:477-487

Ettazarizini S, El Mahmouhi N (2004) Vulnerability mapping of the turonian limestone aquifer in the phosphate plateau (Morocco). Environ Geol 46:113-117

Florinsky IV (2000) Relationships between topographically expressed zones of flow accumulation and sites of fault intersection: analysis by means of digital terrain modelling. Environ Model Softw 15(1):87-100

Fernández D, Lutz M (2010) Urban flood hazard zoning in Tucumán Province, Argentina, using GIS and multicriteria decision analysis. Eng Geol 111:90-98

Faust N, Anderson WH, Star JL (1991) Geographic information systems and remote sensing future computing environment. Photogram Eng Remote Sens 57(6):655-668

Gaur S, Chahar BR, Graillot D (2011) Combined use of groundwater modeling and potential zone analysis for management of groundwater. Int J Appl Earth Obs 13:127-139

Gerrard AJ (1981) Soils and Landforms. An Integration of Geomorphology and Pedology. George Allen and Unwin, London, p 219

Glenn CR et al (2012) Lahaina Groundwater Tracer Study—Lahaina, Maui, Hawaii. Final Interim Report prepared from the State of Hawaii DOH, the U.S. EPA, and the U.S. Army Engineer Research and Development Center

Gokceoglu C, Aksoy H (1996) Landslide susceptibility mapping of the slopes in the residual soils of the Mengen region (Turkey) by deterministic stability analyses and image processing techniques. Eng Geol 44:147-161

Goodchild MF (1993) The state of GIS for environmental problemsolving. In: Goodchild MF, Parks BO, Steyaert LT (eds) Environmental modeling with GIS. Oxford University Press, New York, pp 8-15

Hosseinali F, Alesheikh AA (2008) Weighting spatial information in GIS for copper mining exploration. Am J App Sci 5:1187-1198

Hinton JC (1996) GIS and remote sensing integration for environmental applications. Int J Geogr Inf Sys 10(7):877-890

Jaafari A, Najafi A, Pourghasemi HR, Rezaeian J, Sattarian A (2014) GIS-based frequency ratio and index of entropy models for landslide susceptibility assessment in the Caspian forest, northern Iran. Int J Environ Sci Tech. doi:10.1007/s13762-013-0464-0

Jha MK, Chowdhury A, Chowdary VM, Peiffer S (2007) Groundwater management and development by integrated remote sensing and geographic information systems: prospects and constraints. Water Resour Manag 21(2):427-467

Jha MK, Chowdary VM, Chowdhury A (2010) Groundwater assessment in salboni block, West Bengal (India) using remote sensing, geographical information system and multi-criteria decision analysis techniques. Hydrogeol J 18:1713-1728

Kaliraj S, Chandrasekar N, Magesh NS (2014) Identification of potential groundwater recharge zones in Vaigai upper basin,
Tamil Nadu, using GIS-based analytical hierarchical process (AHP) technique. Arab J Geosci 7:1385-1401

Kane WF, Peters DC, Speirer RA (1996) Remote sensing in investigation of engineered underground structures. J Geotech Eng 122:674-681

Koike K, Nagano S, Kawaba K (1998) Construction and Analysis of Interpreted fracture planes through combination of satellteimage dervied lineaments and digital elevation model. Comput Geosci 24:573-583

Leary O, Freidman DW, Pohn JD (1976) Lineaments, linear, lineation-some proposed new standards for old terms. Geol Soc Am Bull 87:1463-1469

Machiwal D, Jha MK, Mal BC (2011) Assessment of groundwater potential in a semi-arid region of India using remote sensing, GIS and MCDM techniques. Water Resour Manag 25:1359-1386

Madan KJ, Chowdary VM, Chowdhury A (2010) Groundwater assessment in salboni block, west Bengal (India) using remote sensing, geographical information systemand multi-criteria decision analysis techniques. Hydrogeol J 18:1713-1728

Madrucci V, Taioli F, Cesar De Araujo C (2008) Groundwater favorability map using GIS multi criteria data analysis on crystalline terrain, Sao Paulo State, Brazil. J Hydrol 357:153-173

Magesh NS, Chandrasekar N, Soundranayagam JP (2012) Delineation of groundwater potential zones in Theni district, Tamil Nadu, using remote sensing, GIS and MIF techniques. Geosci Front 3(2):189-196

Malczewski J (1999) GIS and multicriteria decision analysis. Wiley, USA, pp 177-192

Manap MA, Sulaiman WNA, Ramli MF, Pradhan B, Surip N (2013) A knowledge-driven GIS modeling technique for groundwater potential mapping at the Upper Langat Basin, Malaysia. Arab J Geosci 6:1621-1637

Manap MA, Nampak H, Pradhan B, Lee S, Sulaiman WNA, Ramli MF (2014) Application of probabilistic-based frequency ratio model in groundwater potential mapping using remote sensing data and GIS. Arab J Geosci 7:711-724

Mogaji KA, Lim HS, Abdullah K (2014) Regional prediction of groundwater potential mapping in a multifaceted geology terrain using GIS-based Dempster-Shafer model. Arab J Geosci. doi:10. 1007/s12517-014-1391-1

Mohammady M, Pourghasemi HR, Pradhan B (2012) Landslide susceptibility mapping at golestan province, Iran: a comparison between frequency ratio, Dempster-Shafer, and weights-ofevidencemodels. J Asian Earth Sci 61:221-236

Moore ID, Grayson RB, Ladson AR (1991) Digital terrain modeling: a review of hydrological, geomorphological and biological applications. Hydrol Process 5:3-30

Moore ID, Gessler PE, Nielsen GA, Peterson GA (1993) Soil attribute prediction using terrain analysis. Soil Sci Soc Am J 57(2):443-452

Musa KA, Akhir JM, Abdullah I (2000) Groundwater prediction potential zone in Langat Basin using the integration of remote sensing and GIS. http://www.gisdevelopment.net. Accessed 24 July 2008

Naghibi SA, Pourghasemi HR, Pourtaghie ZS, Rezaei A (2014) Groundwater qanat potential mapping using frequency ratio and Shannon's entropy models in the moghan watershed. Iran Earth Sci Inform. doi:10.1007/s12145-014-0145-7

Nampak H, Pradhan B, Manap MA (2014) Application of GIS based data driven evidential belief function model to predict groundwater potential zonation. J Hydrol 513:283-300

Nazari A, Salarirad MM, Bazzazi AA (2012) Landfill site selection by decision-making tools based on fuzzy multi attribute decisionmaking method. Environ Earth Sci 65:1631-1642 
Nefeslioglu H, Gokceoglu C, Sonmez H (2008) An assessment on the use of logistic regression and articial neural networks with different sampling strategies for the preparation of landslide susceptibility maps. Eng Geol 97:171-191

Negnevitsky M (2002) Artificial intelligence: a guide to intelligent systems. Addison-Wesley/Pearson, Harlow, p 394

Neshat A, Pradhan B, Pirasteh S, Shafri HZM (2013) Estimating groundwater vulnerability to pollution using modified DRASTIC model in the Kerman agricultural area Iran. Environ Earth Sci. doi:10.1007/s12665-013-2690-7

Nosrati K, Eeckhaut MVD (2012) Assessment of groundwater quality using multivariate statistical techniques in hashtgerd plain, Iran. Environ Earth Sci 65:331-344

Oh HJ, Kim YS, Choi JK, Park E, Lee S (2011) GIS mapping of regional probabilistic groundwater potential in the area of Pohang City, Korea. J Hydrol 399:158-172

Ozdemir A (2011a) GIS-based groundwater spring potential mapping in the Sultan Mountains (Konya, Turkey) using frequency ratio, weights of evidence and logistic regression methods and their comparison. J Hydrol 411(3-4):290-308

Ozdemir A (2011b) Using a binary logistic regression method and GIS for evaluating and mapping the groundwater spring potential in the sultan mountains (Aksehir, Turkey). J Hydrol 405(1):123-136

Page ML, Berjamy B, Fakir Y, Bourgin F, Jarlan J, Abourida A, Benrhanem M, Jacob G, Huber M, Sghrer F, Simonneaux V, Chehbouni G (2012) An integrated DSS for groundwater management based on remote sensing. The case of a semi-arid aquifer in Morocco. Water Resour Manag 26:3209-3230

Pourghasemi HR, Beheshtirad M (2014) Assessment of a data-driven evidential belief function model and GIS for groundwater potential mapping in the Koohrang Watershed, Iran. Geocarto Int. 10.1080/10106049.2014.966161

Pourghasemi HR, Mohammady M, Pradhan B (2012a) Landslide susceptibility mapping using index of entropy and conditional probability models in GIS: Safarood Basin, Iran. Catena 97:71-84

Pourghasemi HR, Moradi HR, Fatemi Aghda SM, Gokceoglu C, Pradhan B (2012b) GIS-based landslide susceptibility mapping with probabilistic likelihood ratio and spatial multi-criteria evaluation models (North of Tehran, Iran). Arab J Geosci 7(5):1857-1878

Pourghasemi HR, Pradhan B, Gokceoglu C (2012c) Application of fuzzy logic and analytical hierarchy process (AHP) to landslide susceptibility mapping at Haraz watershed, Iran. Nat Hazards 63:965-996

Pourghasemi HR, Pradhan B, Gokceoglu C (2012d) Remote sensing data derived parameters and its use in landslide susceptibility assessment using Shannon's Entropy and GIS. Appl Mech Mater 225:486-491

Pourghasemi HR, Moradi HR, Fatemi Aghda SM (2013a) Landslide susceptibility mapping by binary logistic regression, analytical hierarchy process, and statistical index models and assessment of their performances. Nat Hazards 69:749-779

Pourghasemi HR, Pradhan B, Gokceoglu C, Mohammadim Moradi HR (2013b) Application of weights-of-evidence and certainty factor models and their comparison in landslide susceptibility mapping at Haraz watershed,Iran. Arab J Geosci 6:2351-2365

Pourtaghi ZS, Pourghasemi HR (2014) GIS-based groundwater spring potential assessment and mapping in the Birjand Township, southern Khorasan Province Iran. Hydrogeol J. doi:10.1007/ s10040-013-1089-6

Pradhan B (2009) Groundwater potential zonation for basaltic watersheds using satellite remote sensing data and GIS techniques. Cent Eur J Geosci 1(1):120-129
Pradhan B (2013) A comparative study on the predictive ability of the decision tree, support vector machine and neuro-fuzzy models in landslide susceptibility mapping using GIS. Comput Geosci 51:350-365

Pradhan B, Lee S (2010) Regional landslide susceptibility analysis using back-propagation neural network model at Cameron Highland, Malaysia. Landslides 7(1):13-30

Prasad RK, Mondal NC, Banerjee P, Nandakumar MV, Singh VS (2008) Deciphering potential groundwater zone in hard rock through the application of GIS. Environ Geol 55(3):467-475

Rahmati O, Nazari Samani A, Mahdavi M, Pourghasemi HR, Zeiniv $\mathrm{H}$ (2014a) Groundwater potential mapping at Kurdistan region of Iran using analytic hierarchy process and GIS. Arab J Geosci. doi:10.1007/s12517-014-1668-4

Rahmati O, Nazari Samani A, Mahmoodi N, Mahdavi M (2014b) Assessment of the contribution of $\mathrm{N}$-fertilizers to nitrate pollution of groundwater in western Iran (case study: Ghorveh-Dehgelan Aquifer). Water Qual, Expo Health. doi:10.1007/ s12403-014-0135-5

Rao BV, Briz-Kishore BH (1991) A methodology for locating potential aquifers in a typical semi-arid region in India using resistivity and hydrogeologic parameters. Geoexploration 27:55-64

Regmi AD, Devkota KC, Yoshida K, Pradhan B, Pourghasemi HR, Kumamoto T, Akgun A (2013) Application of frequency ratio, statistical index, and weights-of-evidence models and their comparison in landslide susceptibility mapping in central Nepal Himalaya. Arab J Geosci. doi:10.1007/s12517-012-0807-z

Saaty TL (1980) The analytic hierarchy process: planning, priority setting. Resource Allocation. McGraw-Hill, New York

Saaty TL (1997) That Is Not the Analytic Hierarchy Process: What the AHP Is and What It Is Not. J Multicriteria Decis Anal 6:324-335

Samy I, Shattri M, Bujang BK, Ahmad RM (2011) Structural geologic control with the limestone bedrock associated with piling problems using remote sensing and GIS: a modified geomorphological method. Environ Earth Sci 66(8):2185-2195. doi:10.1007/s12665-011-1440-y

Sarkar BC, Deota BS, Raju PLN, Jugran DK (2001) A geographic Information system approach to evaluation of groundwater potentiality of Shamri micro-watershed in the Shimla Taluk, Himachal Pradesh. J Indian Soc Remote Sens 29(3):151-164

Shahid S, Nath SK, Kamal ASMM (2002) GIS integration of remote sensing and topographic data using fuzzy logic for ground water assessment in Midnapur District, India. Geocarto Int 17(3):69-74

Shekhar S, Pandey AC (2014) Delineation of groundwater potential zone in hard rock terrain of India using remote sensing, geographical information system (GIS) and analytic hierarchy process (AHP) techniques. Geocarto Int. doi:10.1080/10106049. 2014.894584

Singh AK, Prakash SR (2003) An integrated approach of remote sensing, geophysics and GIS to evaluation of groundwater potentiality of Ojhala sub-watershed, Mirjapur District, U.P., India. http://www.gisdevelopment.net. Accessed on 25 Aug 2007

Solomon S, Quiel F (2006) Groundwater study using remote sensing and geographic information systems (GIS) in the central highlands of Eritrea. Hydrogeol J 14:1029-1041

Stafford DB (Ed) (1991) Civil engineering applications of remote sensing and geographic information systems. ASCE, New York

Tehrany MS, Pradhan B, Jebur MN (2013) Spatial prediction of flood susceptible areas using rule based decision tree (DT) and a novel ensemble bivariate and multivariate statistical models in GIS. J Hydrol 504:69-79 
Tehrany MS, Pradhan B, Jebur MN (2014) Flood susceptibility mapping using a novel ensemble weights-of-evidence and support vector machine models in GIS. J Hydrol 512:332-343

Vaux H (2011) Groundwater under stress: the importance of management. Environ Earth Sci 62:19-23

Vieux BE (2004) Distributed hydrologic modeling using GIS. Water Sci Tech Libr, vol. 48. Kluwer Academic Publishers, p 312

Yesilnacar EK (2005) The application of computational intelligence to landslide susceptibility mapping in Turkey. Ph.D Thesis, Department of Geomatics the University of Melbourne, p 423
Yilmaz I (2009) Landslide susceptibility using frequency ratio, logistic regression, artificial neural networks and their comparison: a case study from Kat landslide (Tokat-Turkey). Comput Geosci 35(6):1125-1138

Zektser IS, Everet LG (eds) (2004) Groundwater Resources of the World and Their Use. UNESCO IHP-VI Series on Groundwater No. 6 